\title{
Hotel employee commitment and satisfaction in Anhui, Province of China
}

$\mathrm{Xu}$, Jun

Lyceum of the Philippines University-Batangas, Philippines (123085391@qq.com)

Felicen, Sevillia S. $\varnothing$

Lyceum of the Philippines University-Batangas, Philippines (ssfelicen@lpubatangas.edu.ph)

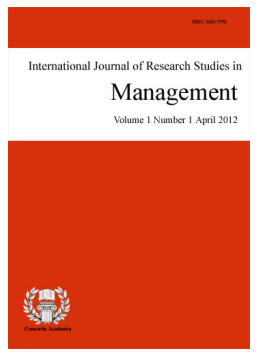

ISSN: 2243-7770 Online ISSN: 2243-7789

OPEN ACCESS

\section{Abstract}

This study aims to determine hotel employee organizational commitment in Anhui, China. Specifically, it will present the profile of respondents; assess organizational commitment in terms of sharing of knowledge, tasks orientation, organizational justice, training and development, incentives and compensation, work environment, wages and benefits, and opportunities and recognition; determine the level of employee satisfaction of hotel staff working in deluxe in terms of working conditions, pay and promotion potential, skills utilization, and work activities; test the significant difference of organizational commitment when grouped according to profile test the significant relationship between organizational commitment and employee satisfaction. The researcher used descriptive research with 385 hotel staff/employees as respondents of the study. Frequency distribution, percentage, ranking, weighted mean, ANOVA and Pearson-r Product Moment Correlation was the statistical test used. Based on the result, hotel staff generally attested to their commitment to their respective organizations in terms of knowledge sharing, task orientation, organization justice, incentive and compensation, working environment, salary and benefits, opportunities, and recognition. Hotel employees are generally satisfied with their jobs in five-star hotels in Anhui, China especially in working conditions and work activities, pay, and promotion while potential and skills are above satisfactory. There are significant differences in the assessment of organizational commitment in terms of educational attainment and monthly income. Organizational commitment is found to be positively related to employee satisfaction.

Keywords: employee satisfaction, hotel, organizational commitment, working conditions 


\section{Hotel employee commitment and satisfaction in Anhui, Province of China}

\section{Introduction}

All hotels have a single primary goal of ensuring they are more profitable, usually associated with hotel success. However, hotels have always tried to look at the factors that lead to the win. Therefore, the hotels have decided to look at employee satisfaction as the main factor ensuring organizational success. Researchers have tried to evaluate these factors with the service profit chain, explaining that customer loyalty triggers profits and growth due to customer satisfaction (Lau, 2000; Myrden \& Kelloway; Yee et al., 2011). Customer loyalty and satisfaction are achieved due to satisfied and productive employees.

The employees' commitment is the main reason why most hotels are drastically growing and making huge profits. Circumstances such as high labor intensiveness, constant employee interaction, and dependence on other colleagues have helped shape the hotel industry. Management of the hotel industry is critical when compared to other sectors. Since most hotels face several severe challenges, this is due to the ever-changing organizational climate that has impacted many organizations. Employee commitment is the fuel that is pushing employees to strive for excellence. Most hotels are working around the clock to ensure that their employees are well motivated, leading to commitment and satisfaction. Many factors affect employee commitment and satisfaction.

The commitment of the hotel industry to organizational justice is very crucial for the success of the business. This has been made possible since the hotels have ensured that all grievances are solved without some employees' biases and favors. All the employees are treated equally when it comes to conflict resolution, thus maintaining high organizational justice standards. The hotel industry is also committed to employee training and commitment. All employees are entitled to compulsory training so that they can be developed according to the organizational standards. As a form of motivation, the employees are taken through a training and development process to ensure that they gain the required skills in their specific workstations. Training is conducted on the job and off the job according to how the management has organized it. Usually, the facilitators are experts in specific areas; hence they possess the needed skills and expertise. Also, the hotel management is committed to the proper allocation of incentives and compensations. All employees are entitled to incentives and adequate compensation. The employees are compensated according to performance and merit.

The hotel industry management has a mechanism that ensures all employees are well compensated, providing all the employees are happy and satisfied with the number of incentives they receive. The organization is also committed to a proper and conducive work environment. The employees need to work in a good background that promotes peace and harmony at the workplace. Employees get easily satisfied when they are appreciated in the workplace. The hotel industry management's commitment to ensure that all employees are entitled to proper wages and benefits is essential in ensuring employee commitment and satisfaction. This is because the employees are easily motivated by the benefits they are receiving from the organization. Due to motivation, they are encouraged to work without supervision towards attaining organizational goals and objectives. Opportunity and recognition is another objective that organizations need to be committed to. Employees feel appreciated when they take part in new opportunity recognition. The employees need to be allowed to take part in opportunity recognition. Hence they adopt the change quickly and take part in ensuring its success. Employees are an essential factor in any organization's success; accordingly, should be well treated and motivated to ensure high productivity and organizational success. Service quality is the foundation of the hotel's survival. Employee satisfaction directly affects the service quality of the hotel, and employee commitment is also related to employee satisfaction (Yang, 2019). Therefore, employee commitment and satisfaction should be taken seriously by all hotel industry management for success and growth.

This paper discussed the various relationships between employee satisfaction and commitment from the 
following factors during the study. The hotels have committed themselves to ensure there is equal sharing of knowledge. This has been made possible by designing the offices to create a conducive space for the employees to have conversations. The conducive conversation space enables the employees to share their knowledge to ensure the business is growing and attaining the set objectives and goals.

\subsection{Objectives of the study}

This study aims to determine hotel employee organizational commitment in Anhui, China. Specifically, assess organizational commitment in terms of sharing of knowledge, tasks orientation, organizational justice, training and development, incentives and compensation, work environment, wages and benefits, and opportunities and recognition; determine the level of employee satisfaction of hotel staff working in deluxe in terms of working conditions, pay and promotion potential, skills utilization, and work activities test the significant relationship between organizational commitment and employee satisfaction

\section{Method}

\subsection{Research design}

The researcher used descriptive research to determine the hotel employees' commitment and level of job satisfaction. A quantitative approach will be used by the researcher. The advantage of the quantitative approach is that they can contribute to the researcher's hard numbers which can be subsidiary in deciding for writing a data conclusion (Brannen, 2017).

\subsection{Respondents of the study}

The respondents of the study will be the staff/employee currently working in the top 10 accredited hotels in Ahui, Province in China. The sample of the study consists of 385 hotel employees.

\subsection{Data gathering instrument}

The first part of the instrument is about the demographic profile of the respondents followed by an adopted questionnaire from the study of Cheah et al. (2016), An Empirical Study on Factors Affecting Organizational Commitment between Generation X for Organizational Engagement for organizational commitment while Employee Satisfaction was adopted from the study Beriales et al. (2017), Level of Employee Satisfaction in Selected Food Establishments for employee satisfaction. The Cronbach alpha results range from .801 to .937 and indicate the reliability of the questionnaire.

\subsection{Data gathering procedure}

The researcher will seek permission from the office of the hotels to survey with their employees. The researcher will visit the hotels to provide the Human Resource Department with a questionnaire for them to disseminate the questionnaire to the staff using the stratified-random sampling technique.

\subsection{Data analysis}

The data gathered will be tallied, interpret, and analyzed using different statistical tools such as frequency distribution, percentage, ranking, weighted mean, ANOVA, and Pearson-r Product Moment Correlation. The profile will be analyzed using frequency, percentage distribution, and ranking. The factors affecting organizational commitment and level of job satisfaction will be analyzed using a weighted mean. The significant difference between demographic profiles and organizational commitment was analyzed using ANOVA or Analysis of Variance. Pearson-r Product Moment Correlation will be used to test the significant relationship between employee commitment and level of job satisfaction. 


\subsection{Ethical considerations}

Some ethical issues are subject to the current study. As mentioned earlier, through a signed letter, all participants submit written acknowledgment of their participation in research. Participants will be fully informed about the goals of the study while being reassured that their responses would be treated as confidential and used only for academic purposes and delicate purposes of research.

\section{Result and discussion}

\section{Table 1}

Assessment in organizational commitment in terms of knowledge sharing

\begin{tabular}{|c|c|c|c|}
\hline Knowledge Sharing & WM & VI & Rank \\
\hline $\begin{array}{l}\text { The company and the employees are willing to share the knowledge with their } \\
\text { colleagues. }\end{array}$ & 3.57 & Strongly Agree & 1 \\
\hline Employees are updated about the announcement of the schedule and monthly meetings. & 3.49 & Agree & 3 \\
\hline Employees are participating in the collaboration of ideas. & 3.48 & Agree & 4 \\
\hline $\begin{array}{l}\text { Employees are participating in different pieces of training and seminars and share them } \\
\text { with colleagues. }\end{array}$ & 3.24 & Agree & 5 \\
\hline \multirow[t]{2}{*}{ The employees are attending meetings together with their colleagues. } & 3.56 & Strongly Agree & 2 \\
\hline & 3.47 & Agree & \\
\hline
\end{tabular}

Table 1 shows the assessment in organization commitment in terms of knowledge sharing. The respondents generally attested to their commitment to their respective organizations in terms of knowledge sharing as expressed in the composite mean of 3.47. The highest-ranking was that the company and the employees are willing to share the knowledge with their colleagues with a weighted mean of 3.57 which the respondents strongly agreed on. The respondents also agreed that employees are updated about the announcement of schedule and monthly meeting which ranked mid with 3.49 weighted mean. This result indicates that the hotels' respective organizations were able to create work environments where the employees do not need to hesitate in sharing the skills and knowledge that they possess with their colleagues. This could imply that they see themselves in a good position where they could be useful for the organization, help out their workmates, and hence, build each other up.

The study of Ipe (2003) considers knowledge sharing as a company's 'supreme vital tactical reserve.' It further explains and even goes by a study of Salleh et al. (2017) recognizing that in an environment of knowledge sharing, employees are motivated and feel more comfortable working with the organization. When employees share their knowledge with others, they become more committed and willing to work together to achieve organizational goals. Additionally, according to Imamoglu et al. (2019), employees in such environments tend to share more to do their job and support activities that add value to the business.

Meanwhile, the lowest weighted mean of 3.24 was accounted to employees participating in different pieces of training and seminars and sharing it with colleagues which were still agreed upon by the respondents. This could imply that while the involved hotels acknowledge training and seminars as an effective means of sharing knowledge, participating employees sometimes do not find them as useful as the management intends them to be. This does not mean, though, that it is a neglected aspect as most employees still generally agreed to this statement.

Rao et al. (2018) relate a common practice among hotels nowadays, and that involves training by masters to their apprentices. According to them, hotel employees, especially newcomers, are usually required to attend two kinds of training sessions: corporate-culture training and departmental training. While the authors do not discredit their importance, they still consider such as a 'low-tier method of knowledge sharing, highlighting tacit knowledge to be better ingrained in the long run through continuous practice and interactions. 
Table 2

Assessment in organizational commitment in terms of task orientation

\begin{tabular}{|c|c|c|c|}
\hline Task Orientation & WM & VI & Rank \\
\hline Employees are informed of the task given. & 3.57 & Strongly Agree & 1 \\
\hline Employees are performing their best to give quality service and products. & 3.52 & Strongly Agree & 2 \\
\hline Employees are aware of the company's goals and objectives. & 3.25 & Agree & 5 \\
\hline Employees follow the company's Standard Operating Procedures & 3.49 & Agree & 4 \\
\hline Employees are applying gained skills and knowledge & 3.49 & Agree & 3 \\
\hline Composite Mean & 3.46 & Agree & \\
\hline
\end{tabular}

Table 2 presents the assessment of organizational commitment in terms of task orientation. Overall, this was agreed upon by the respondents as expressed in the composite mean of 3.46. Top on the list was that employees are informed of the task given with a weighted mean of 3.57, a statement strongly agreed upon by the respondents. At the third rank, respondents agreed that the employees are applying gained skills and knowledge with a weighted mean of 3.49 .

The results reveal that the hotel employees work best when they are fully aware of the task given to them. A crucial aspect of hotel workforce management, task orientation ensures that the employees can perform their jobs well, and wastage and mistakes are reduced.

According to Forsyth (2010), task orientation allows the duties to be delegated with the knowledge that the employee whom the obligations are charged to will perform the tasks diligently, thus completing them on time and in a more productive way. Nawaz and Khan (2016) emphasize the role of team leaders in task orientation. Team leaders' involvement ensures that a greater concern about the welfare of their fellow employees is shown, which then translates into the employees' expression of their appreciation towards the work they are doing. Those employees who undergo task orientation together develop a strong group efficacy, the achievement of group goals, and group satisfaction linked to the general group performance.

However, at the last spot is the employees' awareness of the company's goals and objectives with a weighted mean of 3.25. While this is still agreed on by the responding hotel employees, it could mean that many of them perform the tasks assigned to them as required by their respective jobs without really knowing the overall general direction that their organizations are going for. If left unchecked, this could pose a challenge to the concerned hotels in the long run.

Boswell (2006) uses the phrase 'line of sight' to describe the employees' understanding of an organization's objectives and how to contribute to those objectives. This line of sight is expected to vary across individual characteristics (e.g., hierarchical level, tenure) and relate to important work outcomes (e.g., work attitudes, turnover), but what is important is for it to be aligned to what the organization stands for, and act to contribute to the overarching mission of the organization.

\section{Table 3}

Assessment in organizational commitment in terms of organizational justice

\begin{tabular}{llll}
\hline \multicolumn{1}{c}{ Organizational Justice } & WM & VI & Rank \\
\hline Employees feel belonging in the organization. & 3.47 & Agree & 1.5 \\
Employees receive equal treatment with all co-workers. & 3.43 & Agree & 4 \\
Employees receive equal treatment from their supervisors. & 3.02 & Agree & 5 \\
Employees receive a fairly distributed task. & 3.45 & Agree & 3 \\
Employees receive the same level of appreciation. & 3.47 & Agree & 1.5 \\
& Composite Mean & 3.37 & Agree \\
\hline
\end{tabular}

Table 3 presents the assessment in organization commitment in terms of organization justice to which the respondents generally agreed as revealed by the composite mean of 3.37. In both items, employees feel belongingness in the organization and employees receive the same level of appreciation tied on the first rank with a 3.47 weighted mean. 
The results show that the environments in the concerned organizations were congenial enough for the employees to feel accepted and valued, indicating a notable presence of organizational justice in their respective organizations. Heery and Noon (2001 cited in Abdeldayem et al., 2021) define organizational belongingness as a strong belief in accepting the goals of the organization and a strong desire to retain membership in it. According to Baumeister and Leary (1995 cited in Ali and Jaaffar, 2020), this sense of belongingness comes with a strong perception of the delivery of justice or fairness in the organization.

The last spot was that the employees receive equal treatment with the supervisors with a weighted mean of 3.02. Despite the general agreement of the respondents, this result could indicate the hotel employees' differing notions about the fairness of treatment and communication delivered by their superiors. Existing literature on the subject describes this aspect of organizational justice as interactional justice (Saunders and Thornbill 2003 cited in Mensah et al., 2016). Interactional justice is also called interpersonal justice in that it is based on the quality of interactions between the employees and their superiors and how they relate to the decision-making process in the organization.

\section{Table 4}

Assessment in organizational commitment in terms of training and development

\begin{tabular}{lccc}
\hline Training and Development & WM & VI & Rank \\
\hline The company provides effective training. & 3.13 & Agree & 3 \\
The company provides regular training about the job. & 3.10 & Agree & 4 \\
The employee receives very productive training that enhances their skills and knowledge. & 3.08 & Agree & 5 \\
The company always offers team-building activities to strengthen the bond of the employees. & 3.31 & Agree & 2 \\
Employees are willing to attend the provided seminars and training. & 3.34 & Agree & 1 \\
& Composite Mean & 3.19 & Agree \\
\hline
\end{tabular}

Table 4 exhibits the assessment of organizational commitment in terms of training and development. The respondents agreed to all the items with a composite mean of 3.19. The first in the list was that the employees are willing to attend the provided seminars and training with a weighted mean of 3.34. The employees' willingness to attend training and seminars also indicates their eagerness to enhance their skills and knowledge in the performance of their tasks. Provided that they are well-structured and relevant to the workers' needs, seminars and training could equip and inspire employees to do better at their job and be more committed to their work and the organization that they belong to.

Literature on the subject highlights the positive influence of attendance to training on employee commitment. The works of Bashir and Long (2015), Dhan (2015), and Sofat et al. (2015) all reinforce the employees' belief that participation in training offers benefits for their jobs or personal lives tends to show high organizational commitment levels. A common theme across these studies is the involvement of several intervening factors affecting employee participation. These include availability and access to training, management support, perceived benefits of training, and employees' intrinsic motivations. If organizations can ensure that these factors are well in place, it could be assumed to stimulate the employees' commitment and feelings of loyalty to the organization.

The third rank was the company that provides effective training with a weighted mean of 3.13 while the list was that the employee receives a very productive training that enhances their skills and knowledge ranked last with a weighted mean of 3.08. With these results, it is important to look not only at the employees' willingness to participate in training but also at the quality of available training.

The study of Ahammad (2013) cites distracting and repetitive training as factors that diminish employee participation. Dunigan (2012) likewise mentions that ineffective training programs do not foster information retention, and frustrate both the attendees and the training administrators. It is therefore imperative that training be properly constructed to promote knowledge gain among employees and make participation such a rewarding experience for them. 
Hotel employee commitment and satisfaction in Anhui, Province of China

\section{Table 5}

Assessment in organizational commitment in terms of incentive and compensations

\begin{tabular}{|c|c|c|c|}
\hline Incentive and Compensations & WM & VI & Rank \\
\hline Employees are entitled to skills and knowledge enhancement through training. & 3.19 & Agree & 4 \\
\hline Employees receive a percentage from the service charge. & 3.21 & Agree & 3 \\
\hline Employees receive bonuses from the management. & 3.00 & Agree & 5 \\
\hline Employees receive incentives for perfect attendance. & 3.29 & Agree & 1 \\
\hline Employees receive tips from the customers for quality service. & 3.24 & Agree & 2 \\
\hline Composite Mean & 3.19 & Agree & \\
\hline
\end{tabular}

Table 5 displays the assessment of organizational commitment in terms of incentive and compensations. The results recorded an agreeable response from the employees with a composite mean of 3.19. The highest weighted mean was accounted to employees receiving incentives for perfect attendance at 3.29. Ranked mid was that employees receive a percentage from the service charge with a weighted mean of 3.21 .

These results could signify the hotels' appreciation for their employees' commitment to report to work regularly. Rewarding them with incentives could further motivate them to be better at their jobs. According to Cheah et al. (2016), employees generally feel motivated when they found out that their jobs are related to things they value. As such, organizations are consistently seeking to satisfy their employees in all sectors to be productive in their daily duties. In the same way, Rubel (2015) and Francoeur et al. (2017) also suggest that incentives and compensation of employees determine their productivity.

Meanwhile, ranking the least with a weighted mean of 3.00 was that the employees receive bonuses from the management. While still obtaining a positive result, the low ranking could be attributed to the differences among hotel organizations in terms of distributing bonuses to their employees. Depending on the organization, bonuses including lump-sum bonus, year-end bonus, or incentive plans among others may be awarded to employees. Both the studies conducted by Cheah et al. (2016) and Kee et al. (2016) reveal that financial rewards such as bonuses produce several benefits - it motivates employees to perform better, make them want to stay in the organization longer, and even attract talented workers to join the organization. Consequently, it is also said to affect the job satisfaction and organizational commitment of employees.

\section{Table 6}

Assessment in organizational commitment in terms of working environment

\begin{tabular}{|c|c|c|c|}
\hline Working Environment & WM & VI & Rank \\
\hline Employees move comfortably in the workplace. & 3.64 & Strongly Agree & 2 \\
\hline Employees work with peers with confidence. & 3.54 & Strongly Agree & 5 \\
\hline The company provides supplies needed for work and is always complete and available. & 3.62 & Strongly Agree & 3 \\
\hline Co-workers are approachable. & 3.59 & Strongly Agree & 4 \\
\hline The company provides a working environment that is enough to work for. & 3.65 & Strongly Agree & 1 \\
\hline Composite Mean & 3.61 & Strongly Agree & \\
\hline
\end{tabular}

Table 6 poses the assessment in organizational commitment in terms of the working environment to which the respondents all strongly agreed based on the composite mean of 3.61. The company provides a working environment that is enough to work for was at the top of the list with a 3.65 weighted mean. At the middle rank was the company provides supplies needed for work and is always complete and available with a weighted mean of 3.62 .

The results could translate to the employees' perception of a conducive working environment in their respective organizations. By extension, the employees' strong agreement on the statements may also signify a high level of commitment to the organization as far as their day-to-day interactions with their coworkers and superiors are concerned. Aronsson et al. (2017) state that personal interactions at the workstation also influence the morale of the employees. Supposedly, whatever that brings an effect to the employee morale on the job also has a significant impact on their job commitment. Irresponsible and less committed employees can change and become more committed and responsible members of the organization if they are exposed to a conducive 
Xu, J., \& Felicen, S. S.

working environment in the workplace.

Last on the list was employees who work with peers with confidence with a weighted mean of 3.54. Still obtaining a strong agreement among respondents, could be translated to the trust that the employees place with their colleagues. This could also be seen to either positively or negatively affect ones' commitment to the organization. The hotel as a workplace is a very social environment, and social interactions between coworkers are necessary for the organization to function well. Casimir et al. (2012) highlight the importance of interpersonal trust or the extent to which a person is confident in and willing to act based on the words, actions, and decisions of another, in facilitating voluntary cooperation among employees without the fear of the other one being exploitative or opportunistic.

Table 7

Assessment in organizational commitment in terms of salary and benefits

\begin{tabular}{|c|c|c|c|c|}
\hline Salary and Benefits & & WM & VI & Rank \\
\hline Employees receive a competitive salary. & & 3.09 & Agree & 4 \\
\hline Employees receive different incentives including seminars and training. & & 3.06 & Agree & 5 \\
\hline Employees receive bonus pay. & & 3.24 & Agree & 2 \\
\hline Employees receive a tip from my customers. & & 3.28 & Agree & 1 \\
\hline \multirow[t]{2}{*}{ Employees receive a percentage from the service charge. } & & 3.23 & Agree & 3 \\
\hline & Composite Mean & 3.18 & Agree & \\
\hline
\end{tabular}

Table 7 presents the assessment of organizational commitment in terms of salary and benefits. It can be seen that the respondents agreed on all items as expressed in the composite mean of 3.18. Employees who receive a tip from my customers led the list with a weighted mean of 3.28 while employees receive a percentage from the service charge ranked third with a weighted mean of 3.23 .

The top result highlights tipping as a common practice in the hospitality industry. Aside from their base salaries, employees working in hotels and restaurants are usually able to augment their income with gratuities or tips coming from their guests. In one way or another, this practice could be seen to influence their commitment to the respective organizations.

Interestingly, the idea of compensation in the form of a tip being an antecedent to employee commitment is not always positive. Miller (2010) suggests that tipping may adversely affect the employees' commitment and by extension, their tenure with an organization. A similar study by Curtis et al. (2009) speculates that the practice of tipping makes the employees more like subcontractors who prioritize excellent tips more than intrinsic motivators such as work interest, promotion room, and gratitude.

On the other hand, the employees receiving different incentives including seminars and training ranked last with a weighted mean of 3.06. Despite the ranking, this statement still elicited a positive response from the employees indicating the conduct of seminars and training for employees as learned in the section about knowledge sharing. However, this could also mean that only several organizations go so far as to incentivize these programs for employees, while several likely impose attendance to training as company requirements.

Dunigan (2012) stresses the contribution of incentives in motivating employees to want to participate and engage in training and seminars. According to her, rewarding learners for participating in training gives them something other than the satisfaction of a job well done and is often the extra push to make training a priority. A caveat to this, however, is that incentives usually are an added cost that can be difficult to get approved, and might seem like a 'throwaway solution.' The key, therefore, is to properly construct training incentives that would yield positive results to both the management and the employees.

Table 8 displays the assessment of organizational commitment in terms of opportunities and recognitions. This was, overall, strongly agreed upon by the respondents at a 3.50 composite mean. Top on the list with a 3.58 weighted mean was the respondents' strong agreement on the statement the company gives compliments as a

88 Consortia Academia Publishing (A Partner of Tourism Educators and Movers of the Philippines) 
Hotel employee commitment and satisfaction in Anhui, Province of China

simple thanks to their employees after their work is accomplished. The third rank was that the company recognizes and gives compliments to employees' accomplishments.

\section{Table 8}

Assessment in organizational commitment in terms of opportunities and recognitions

\begin{tabular}{|c|c|c|c|}
\hline Opportunities and Recognitions & WM & VI & Rank \\
\hline $\begin{array}{l}\text { The company gives compliments as; a simple thank you was given to me after my work } \\
\text { is accomplished. }\end{array}$ & 3.58 & Strongly Agree & 1 \\
\hline The company has established a policy on promotion and recognition. & 3.50 & Agree & 4 \\
\hline The company recognizes and gives compliments to employees' accomplishments. & 3.50 & Agree & 3 \\
\hline The company awards employees because of perfect attendance. & 3.42 & Agree & 5 \\
\hline The employees receive a promotion recently. & 3.51 & Strongly Agree & 2 \\
\hline Composite Mean & 3.50 & Strongly Agree & \\
\hline
\end{tabular}

Working in a hotel can be a very demanding job, the employees see the hotels' appreciation of their work from the compliments they receive for a job well done. While the most common recognitions come in the form of institutional rewards such as awards, social recognition, cash or non-cash incentives, verbal compliments and praises also have perceptible effects on the employees' attitudes and commitment towards their respective organizations. The study by Cheon (2016) reveals that verbal compliments especially those coming from superiors, customers, and colleagues have significant positive impacts on the feelings and job attitudes of hotel employees on a personal and organizational level. He goes on to state that frequent compliments within a non-excessive range will spread a positive atmosphere throughout the given organization.

On the other hand, the company awards an employee because of perfect attendance ranked last with a 3.42 weighted mean. While the results in the previous section about incentives and compensation reveal that organizations provide incentives who report to work daily, it does not mean that organizations emphasize it as a feat to recognize. Reporting to work regularly is something that must be expected of employees. Thus, this result may suggest that awarding employees with perfect attendance is not a very common practice in hotels in Anhui, China. This could further imply that these organizations place greater emphasis on different outcomes from their employees other than just attendance.

As the study of Beazley (2010) relates, many employees feel that the perfect attendance award is unobtainable and that they only see some form of importance in being awarded such. By extension, it could be assumed that both the involved hotel managements and their workforces see employee commitment as going beyond mere reporting to work.

Table 9

Assessment in employee satisfaction in terms of working conditions

\begin{tabular}{llll}
\hline & Working Conditions & WM & VI \\
\hline Location of Work & & 3.64 & Highly Satisfied \\
Safety & 3.64 & Highly Satisfied & 2 \\
Hours work each week & 3.53 & Highly Satisfied \\
Amount of paid vacation/sick leave offered & 3.65 & Highly Satisfied & Highly Satisfied \\
\end{tabular}

Table 9 shows the assessment of employee satisfaction in terms of working conditions. It can be gleaned that the employees were highly satisfied with their current working conditions as expressed in the composite mean of 3.62. The highest weighted mean is observed to the amount of paid vacation/sick leave offered with a weighted mean of 3.65. In other words, the hotel employees claim to be highly satisfied with the fringe benefits that they are receiving from their respective companies.

According to Totenhagen et al. (2016), most employees today consider employee benefits to be as crucial as the basic pay they are receiving. If they are entitled to better benefits, they will work diligently due to the motivation they receive. Likewise, the results of the studies of Artz (2010) and Abdullah et al. (2011) both reflect 
a positive correlation between benefits package and job satisfaction and loyalty. The latter study specifies that the benefits package takes into account factors such as the amount of vacation, sick leave policy, amount of health care paid for by the organization, and dental benefits. Furthermore, the former declares that the provision of these benefits can even be linked to important productivity measures such as lower quit rates and absenteeism.

On the other hand, hours of work each week were obtained with a weighted mean of 3.53. The hospitality industry works on a $24 / 7$ basis with employees usually being required to work for long and unpredictable hours. It is interesting to note that despite the ranking, the respondents of the present study still report being highly satisfied with the number of hours they spend during their work duties.

This contrasts with most existing literature relating long working hours in hotels to employee satisfaction and engagement. Mokaya et al. (2013), Alqusayer (2016) both identify long working hours together with work pressure, low level of treatment, bad working environment, fewer promotion opportunities, work unfairness, and low salary level to affect employee satisfaction and even cause them to resign from work. Curiously, the results of the present study open the possibility that intervening factors could be attributed to result to the hotel employees' high level of satisfaction in terms of their working hours.

Table 10

Assessment in employee satisfaction in terms of pay and promotional potential

\begin{tabular}{|c|c|c|c|}
\hline Pay and Promotional Potential & WM & VI & Rank \\
\hline Salary & 3.12 & Satisfied & 4 \\
\hline Opportunities for Promotion & 3.26 & Satisfied & 2 \\
\hline Benefits & 3.16 & Satisfied & 3 \\
\hline Job securities & 3.42 & Satisfied & 1 \\
\hline & 3.24 & Satisfied & \\
\hline
\end{tabular}

Table 11 shows the assessment in employee satisfaction in terms of pay and promotional potential which has a 3.24 composite mean and shows that the respondents were satisfied in all items. Job securities led the list with a composite mean of 3.42. Considering the very nature of the hospitality industry, this could be interpreted as the employees' satisfaction with the level of security that they have with their current hotel jobs.

Job security is a critical attribute that workers consider in evaluating their work environments. Alquyaser (2016) names it as one of the three motivational factors that workers find important, along with good wages and opportunities for advancement and development. Consequently, this can also be deliberated as an antecedent to employee satisfaction and loyalty.

Conversely, salary ranked the lowest with a weighted mean of 3.12. This implies that the employees are satisfied with the salaries they receive but not as much as with the other aspects relating to paying and promotion potential. Several studies verify that an employee's salary direct influences his or her decision to join and stay in an organization. As posited by Rubel (2015), workers who are financially contented with their job and work situations are likely to be more committed to the organization than those who are not satisfied.

\section{Table 11}

Assessment in employee satisfaction in terms of use of skills

\begin{tabular}{|c|c|c|c|c|}
\hline Use of Skills & & WM & VI & Rank \\
\hline Opportunity to learn new skills & & 3.28 & Satisfied & 2 \\
\hline Opportunity to utilize your skills \& talents & & 3.32 & Satisfied & 1 \\
\hline Opportunity for advancement & & 3.26 & Satisfied & 3 \\
\hline Support for additional training & & 3.15 & Satisfied & 4 \\
\hline & Composite Mean & 3.25 & Satisfied & \\
\hline
\end{tabular}

Table 11 exhibits the assessment of employee satisfaction in terms of the use of skills. It can be observed that the respondents were satisfied with all uses of their skills since the computed composite mean was 3.25. 
Hotel employee commitment and satisfaction in Anhui, Province of China

First on the list is the opportunity to utilize the employees' skills \& talents with a weighted mean of 3.32. This indicates that employees are satisfied when they can showcase their skills and talents in the performance of their jobs. Hotel workforces are mostly composed of highly skilled workers, and the nature of their jobs provides a lot of opportunities where their skills and talents could be applied.

The studies of Ali et al. (2016) and Ukil (2016) both report a positive association between skills utilization and job satisfaction. Their works suggest that when employees fully utilize their skills, it increases their attitude towards putting more effort to achieve their desired goals. In other words, employees tend to be more satisfied when they feel that their skills are effectively utilized. As such, organizations should continuously and consistently aim to utilize the skills of employees effectively in a facilitative, rather than an inhibitive, process that will encourage them into exerting more effort. Effective application of skills within the workplace leads to high performance.

Meanwhile, support for additional training recorded the lowest rating of 3.15. This does not necessarily indicate a lack of management support in the employees' participation in training activities as it is still reported to have obtained a satisfactory response. However, this result could imply a need to look into the quality of training provided to the hotel employees.

Training is an effective means to share knowledge and enhance the skills of the workforce. Nevertheless, participating employees sometimes do not find them as useful as the management intends them to be. As reported by Ahammad (2013), some employees may cite distracting and repetitive training as factors that could diminish their participation, and by extension, their satisfaction.

Table 12

Assessment in employee satisfaction in terms of work activities

\begin{tabular}{lccc}
\hline & Work Activities & WM & VI \\
\hline Flexibility in scheduling & 3.52 & Highly Satisfied & 2 \\
Variety of job responsibilities & 3.51 & Highly Satisfied & 3.5 \\
Degree of independence associated with your work roles & 3.53 & Highly Satisfied & 1 \\
Adequate opportunity for periodic changes in duties & 3.51 & Highly Satisfied & 3.5 \\
& Composite Mean & 3.52 & Highly Satisfied \\
\hline
\end{tabular}

Table 12 shows the assessment of employee satisfaction in terms of work activities. It can be observed that the respondents were highly satisfied with all the work activities with a composite mean of 3.52. The degree of independence associated with the employees' work roles was first on the list with a 3.53 weighted mean. This implies that the hotel employees are highly satisfied with the level of autonomy that they can exercise in the performance of their jobs. Several studies prove the relationship of job autonomy to employee satisfaction. It reveals that as a worker's control over how a job is done increases, the level of job satisfaction also increases. For Saragih (2011), workers with job autonomy are satisfied feel that they are trusted enough to perform their tasks and make decisions with minimal intervention

Meanwhile, the variety of job responsibilities and adequate opportunity for periodic changes in duties were both at the last spot with a 3.51 weighted mean. Despite ranking last, these components still indicate the employee's high level of satisfaction in terms of the job rotation practiced by their respective organizations.

Table 13

Relationship between Assessment in Organizational Commitment and Employee Satisfaction

\begin{tabular}{|c|c|c|c|c|c|c|c|c|c|c|c|c|}
\hline \multirow[b]{2}{*}{$\begin{array}{c}\text { Organizational } \\
\text { Commitment }\end{array}$} & \multicolumn{3}{|c|}{ Working Conditions } & \multicolumn{3}{|c|}{$\begin{array}{c}\text { Pay and Promotional } \\
\text { Potential }\end{array}$} & \multicolumn{3}{|c|}{ Use of Skills } & \multicolumn{3}{|c|}{ Work Activities } \\
\hline & $\mathrm{r}$ & $\mathrm{P}$ & I & $\mathrm{R}$ & $\mathrm{P}$ & I & $\mathrm{R}$ & $\mathrm{p}$ & I & $\mathrm{r}$ & $\mathrm{p}$ & I \\
\hline $\begin{array}{c}\text { Knowledge } \\
\text { Sharing }\end{array}$ & $.664 * *$ & $<0.001$ & $\mathrm{~S}$ & $.762 * *$ & $<0.001$ & $\mathrm{~S}$ & $.810 * *$ & $<0.001$ & $S$ & $.808 * *$ & $<0.001$ & $\mathrm{~S}$ \\
\hline Task Orientation & $.613 * *$ & $<0.001$ & S & $.725^{* * *}$ & $<0.001$ & $\mathrm{~S}$ & $.787 * *$ & $<0.001$ & S & $.777 * *$ & $<0.001$ & $\mathrm{~S}$ \\
\hline $\begin{array}{l}\text { Organizational } \\
\text { Justice }\end{array}$ & $.568 * *$ & $<0.001$ & $S$ & $.808 * *$ & $<0.001$ & $S$ & $.848^{* *}$ & $<0.001$ & $\mathrm{~S}$ & $.808 * *$ & $<0.001$ & $\mathrm{~S}$ \\
\hline
\end{tabular}


Xu, J., \& Felicen, S. S.

\begin{tabular}{|c|c|c|c|c|c|c|c|c|c|c|c|}
\hline $\begin{array}{l}\text { Training and } \\
\text { Development }\end{array}$ & $.619 * *$ & $<0.001$ & S & $.919 * *$ & $<0.001$ & S & $.905 * *$ & $<0.001$ & S & $.855^{* *}$ & $<0.001$ \\
\hline $\begin{array}{l}\text { Incentive and } \\
\text { Compensations }\end{array}$ & $.571 * *$ & $<0.001$ & S & $.903 * *$ & $<0.001$ & S & $.898 * *$ & $<0.001$ & S & $.850 * *$ & $<0.001$ \\
\hline $\begin{array}{c}\text { Working } \\
\text { Environment }\end{array}$ & $.733 * *$ & $<0.001$ & S & $.608 * *$ & $<0.001$ & S & $.641^{* *}$ & $<0.001$ & $\mathrm{~S}$ & $.677 * *$ & $<0.001$ \\
\hline $\begin{array}{l}\text { Salary and } \\
\text { Benefits }\end{array}$ & $.570 * *$ & $<0.001$ & S & $.921 * *$ & $<0.001$ & S & $.899 * *$ & $<0.001$ & S & $.851 * *$ & $<0.001$ \\
\hline $\begin{array}{l}\text { Opportunities } \\
\text { and } \\
\text { Recognitions }\end{array}$ & $.722 * *$ & $<0.001$ & S & $.808 * *$ & $<0.001$ & S & $.836^{* *}$ & $<0.001$ & S & $.863^{* *} *$ & $<0.001$ \\
\hline
\end{tabular}

Legend: Significant at p-value < 0.05; R - Rejected; FR - Fail to Reject; S - Significant; NS - Not Significant

Table 13 presents the relationship between the assessment of organizational commitment and employee satisfaction. There is a significant relationship between assessment in organizational commitment in terms of sharing of knowledge, tasks orientation, organizational justice, training and development, incentives and compensation, work environment, salary and benefits, and opportunities and recognition and level of employee satisfaction of hotel staff working in deluxe in terms of working conditions, pay and promotion potential, skills utilization, and work activities since the computed $\mathrm{p}$ values are less than 0.05 level of significance. This implies that the higher the assessment in organizational commitment in terms of sharing of knowledge, tasks orientation, organizational justice, training and development, incentives and compensation, work environment, salary and benefits, and opportunities and recognition the higher also the level of employee satisfaction of hotel staff working in deluxe in terms of working conditions, pay and promotion potential, skills utilization, and work activities.

The above results verify that organizational commitment is directly correlated with employee satisfaction. Both concepts may be interpreted as emotions felt by the employees: organizational commitment is emotion directed to their organization, while job satisfaction is emotion directed towards their work. In terms of the direction of the relationship between these two constructs, existing literature asserts organizational commitment to be an extension of job satisfaction. In other words, the hotel employees' level of satisfaction with their jobs translates into emotions that lead to their sense of commitment to the organization.

This notion has been proven by several earlier studies. In the study of Mathur et al. (2013), the independent variable 'job satisfaction has an impact on the dependent variable 'organizational commitment.' They inferred that when employees receive what they expect from their jobs, they can be more attached to their work rather than to just work. Meanwhile, Ismail and Razak (2016) attribute employee satisfaction to both intrinsic (job scope, job variety, and attention to suggestions) and extrinsic (physical working conditions, recognition, management style, job security) factors. Their study confirms that when employees are satisfied both intrinsically and extrinsically, it may lead to a greater commitment to their organizations. Finally, Culibrk et al. (2018) explain job satisfaction as the positive attitudes, which when fostered, could turn into organizational commitment characterized by the employee's attachment to the organization.

\section{Conclusions and Recommendations}

Hotel staff generally attested to their commitment to their respective organizations in terms of knowledge sharing, task orientation, organization justice, incentive and compensation, working environment, salary and benefits, opportunities, and recognition. Hotel employees are generally satisfied with their jobs in five-star hotels in Anhui, China especially in working conditions and work activities, pay, and promotion while potential and skills are above satisfactory. There are significant differences in the assessment of organizational commitment in terms of educational attainment and monthly income. Organizational commitment is found to be positively related to employee satisfaction

The hotel may further increase the salaries and benefits of employees. Adjust the compensation strategy through the compensation system design itself and deepen the reform of the salary system and redesign the scientific salary system. The hotel may spend more time on safety at work. Especially now that the COVID-19 
Hotel employee commitment and satisfaction in Anhui, Province of China

epidemic is still ongoing, employees have higher requirements for the hotel's working environment and safety. The hotel may provide more opportunities for Promotion to employees. The hotel should establish a sound promotion mechanism. The hotel may provide more changes for employees to learn skills and get additional training. Future researchers may conduct another study using other variables such as commitment and satisfaction.

\section{References}

Abdeldayem, M. M., Al Deeb, H., Mohamed, A., \& Al Shaikh, M. A. (2021). Impact of administrative empowerment on organizational belongingness: Evidence from Bahrain. International Journal of Information, Business and Management, 13(3), 114-131.

Abdullah, R., Musa, M., Zahari, H., Rahman, R., \& Khalid, K. (2011). The study of employee satisfaction and its effects towards loyalty in hotel industry in Klang Valley, Malaysia. International Journal of Business and Social Science, 2(3), 147-155.

Ahammad, S. (2013). Importance of training in the hotel industry: A case study of Hilton Hotel, Cyprus. Master's Thesis. Södertörns University.

Ali, A. A., Edwin, O., \& Tirimba, O. I. (2015). Analysis of extrinsic rewards and employee Satisfaction: Case of somtel company in Somaliland.

Ali, G., \& Jaaffar, A. R. (2020). The effect of organization justice, job crafting, appreciative leadership on workplace belongingness. Aegaeum, 8, 2626-2638.

Alias, N. E., Othman, R., Hamid, L. A., Salwey, N. S., Romaiha, N. R., Samad, K. A., \& Masdek, N. R. N. M. (2018). Managing job design: The roles of job rotation, job enlargement and job enrichment on job satisfaction. Journal of Economic \& Management Perspectives, 12(1), 397-401.

Alqusayer, A. (2016). Drivers of hotel employee motivation, satisfaction and engagement in Riyadh, the kingdom of Saudi Arabia (Order No. 10118089). Available from ABI/INFORM Global. (1803634132).

Aronsson, G., Theorell, T., Grape, T., Hammarström, A., Hogstedt, C., Marteinsdottir, I., ... \& Hall, C. (2017). A systematic review including meta-analysis of work environment and burnout symptoms. BMC Public Health, 17(1), 1-13.

Artz, B. (2010). Fringe benefits and job satisfaction. International Journal of Manpower, 31(6), 626-644. https://doi.org/10.1108/01437721011073346

Bashir, N., \& Long, C. S. (2015). The relationship between training and organizational commitment among academicians in Malaysia. Journal of Management Development.

Beazley, A. A. (2010). Analysis of employee engagement at company XYZ (Doctoral dissertation). University of Wisconsin--Stout.

Beriales, M. R. P., Permocillo, D. G. J., Bartizo, C. M. C., \& Porras, C. P. (2017). Level of job satisfaction of the employees in selected fast food establishments. CEBU International Conference on Studies in Arts, Social Sciences and Humanities (SASSH-17) Jan. 26-27, Cebu (Philippines)

Boswell, W. (2006). Aligning employees with the organization's strategic objectives: Out of 'line of sight', out of mind. International Journal of Human Resource Management, 17, 1489-1511. https://doi.org/10.1080/09585190600878071

Brannen, J. (2017). Combining qualitative and quantitative approaches: an overview. Mixing methods: Qualitative and Quantitative Research, 3-37.

Casimir, G., Lee, K., \& Loon, M. (2012). Knowledge sharing: Influences of trust, commitment and cost. Journal of Knowledge Management, 16(5), 740-753. https://doi.org/10.1108/13673271211262781

Cheah, C. S., Chong, V. S. W., Yeo, S. F., \& Pee, K. W. (2016). An empirical study on factors affecting organizational commitment among generation X. Procedia-Social and Behavioral Sciences, 219 , 167-174.

Cheon, Y.S. (2016). The effects of compliments on the feelings of job attitudes of hotel employees. International Review of Management and Marketing, 6(3), 584-589.

Curtis, C., Upchurch, R., \& Severt, D. (2009). Employee motivation and organizational commitment: A 
comparison of tipped and non-tipped restaurant employees. International Journal of Hospitality \& Tourism Administration, 10, 253-269. https://doi.org/10.1080/15256480903088469

Dunigan, S. (2012). The motivational push: Incentives in training' in training industry. Retrieved from https://rainingindustry.com/articles/performance-management/the-motivational-push-incentives-in-trai ning/

Forsyth, D. R. (2010). Group dynamics (5th ed.). Belmont, CA: Wadsworth Cengage Learning.

Francoeur, C., Melis, A., Gaia, S., \& Aresu, S. (2017). Green or greed? An alternative look at CEO compensation and corporate environmental commitment. Journal of Business Ethics, 140(3), 439-453.

Ipe, M. (2003). The praxis of knowledge sharing in organizations: A case study (Order No. 3092750). Available from ABI/INFORM Global. (305330858). Retrieved from

Ipe, M. (2003) Knowledge sharing in organizations: A Concfromin rk. Human Resource Dpersont Review, 2, 337-359. https://doi.org/10.1177/1534484303257985

Jamaludin, Z. (2009). Perceived organizational justice and its impact to the development of commitments: a regression analysis. World Journal of Management, 1(1), 49-61.

Lau, R. S. (2000). Quality of work life and performance-An ad hoc investigation of two key elements in the service profit chain model. International journal of service industry management.

Lobel Trong, T. T., Ho Thi, V. H., \& Baker, J. (2021). When supportive workplaces positively help work performance. Baltic Journal of Management, 16(2), 208-227. https://doi.org/10.1108/BJM-06-2020-0220

Mensah, H. K., Asiamah, N., \& Mireku, K. (2016). The effect of organizational justice delivery on organizational commitment. Journal of Global Responsibility, 7(2), 196-209. https://doi.org/10.1108/JGR-06-2016-0015

Miller, B. (2010). Compensation practices in restaurants and the impact on service quality. Journal of Foodservice Business Research, 13, 24-35. https://doi.org/10.1080/15378021003595913

Mokaya, S. O., Musau, J. L., Wagoki, J., \& Karanja, K. (2013). Effects of organizational work conditions on employee job satisfaction in the hotel industry in Kenya. International Journal of Arts and Commerce, 2(2), 79-90.

Myrden, S. E., \& Kelloway, E. K. (2015). Leading to customer loyalty: a daily test of the service-profit chain. Journal of Services Marketing.

Nawaz, Z. A. K. D. A., \& Khan, I. (2016). Leadership theories and styles: A literature review. Leadership, 16(1), 1-7.

Rao, Y., Yang, M., \& Yang, Y. (2018). Knowledge sharing, organizational learning and service innovation in tourism. Journal of Service Science and Management, 11, 510-526. https://doi.org/10.4236/jssm.2018.115035

Rubel, M. R. B., \& Kee, D. M. H. (2015). High commitment compensation practices and employee turnover intention: Mediating role of job satisfaction. Mediterranean Journal of Social Sciences, 6(6 S4), 321-321.

Salleh, S. M., Ismail, S. N., Hamzah, S. F. M., Zahari, A. S. M., Mohammed, N. H., \& Abdullah, N. (2017). Knowledge sharing and organizational commitment in organization. Journal of Applied Environmental Bio-Sciences, 7(58), 37-40.

Saragih, S. (2015). The effects of job autonomy on work outcomes: Self efficacy as an intervening variable. International Research Journal of Business Studies, 4(3).

Sofat, K., Kiran, R., \& Kaushik, S. (2015). Management of organizational change and its impact on commitment: A study of select Indian IT Companies. Global Business \& Management Research, 7(3).

The Reflektive Team. (2019). Why align employee goals and objectives with business goals' in reflective. Retrieved from https://www.reflektive.com/blog/why-align-employee-goals-and-objectives-with-business-goals/

Totenhagen, C. J., Hawkins, S. A., Casper, D. M., Bosch, L. A., Hawkey, K. R., \& Borden, L. M. (2016). Retaining early childhood education workers: A review of the empirical literature. Journal of Research in Childhood Education, 30(4), 585-599.

94 Consortia Academia Publishing (A Partner of Tourism Educators and Movers of the Philippines) 
Ukil, M. I. (2016). The impact of employee empowerment on employee satisfaction and service quality: Empirical evidence from financial enterprizes in Bangladesh. Verslas: teorija ir praktika, 17(2), 178-189.

Wang, X., Liao, J., Xia, D., \& Chang, T. (2010). The impact of organizational justice on work performance: Mediating effects of organizational commitment and leader-member exchange. International Journal of Manpower, 31(6), 660-677. https://doi.org/10.1108/01437721011073364

Yang, J. (2019). McDonald's customer satisfaction research (Master's thesis). Tianjin Normal University. https://kns.cnki.net/KCMS/detail/detail.aspx?dbname=CMFD202002\&filename=1020744048.nh

Yee, R. W., Yeung, A. C., \& Cheng, T. C. E. (2011). The service-profit chain: An empirical analysis in high-contact service industries. International Journal of Production Economics, 130(2), 236-245. 
Xu, J., \& Felicen, S. S.

96 Consortia Academia Publishing (A Partner of Tourism Educators and Movers of the Philippines) 